Journal of Applied Pharmaceutical Science Vol. 5 (12), pp. 056-060, December, 2015

Available online at http://www.japsonline.com

DOI: $10.7324 / J A P S .2015 .501209$

ISSN 2231-3354 (cc) EY-NC-SA

\title{
Chemical composition and antibacterial activity of the essential oil of Thymus ciliatus growing wild in North Eastern Algeria
}

\author{
Sonia HENI ${ }^{1}$, Salima BENNADJA ${ }^{2}$, Abdelghani DJAHOUDI ${ }^{1,3 *}$ \\ ${ }^{1}$ Department of Biochemistry, Faculty of Sciences, University Badji Mokhtar, Annaba, Algeria. \\ ${ }^{2}$ Laboratory of Biochemistry and Environmental Toxicology, Faculty of Sciences, University Badji Mokhtar, Annaba, Algeria. \\ ${ }^{3}$ Laboratory of Microbiology, Department of Pharmacy, Faculty of Medicine, University Badji Mokhtar, Annaba, Algeria.
}

\begin{tabular}{l} 
ARTICLE INFO \\
\hline Article history: \\
Received on: 17/08/2015 \\
Revised on: 30/09/2015 \\
Accepted on: 19/10/2015 \\
Available online: $27 / 12 / 2015$ \\
\hline Key words: \\
Thymus ciliates, Essential oil, \\
Antibacterial activity, \\
Bacillus cereus, Listeria \\
monocytogenes.
\end{tabular}

\section{INTRODUCTION}

Bacillus cereus, a gram-positive rod has a reputation as a foodborne pathogen responsible for poisoning causing diarrheal or emetic syndromes (Tossa et al., 2009). It is an opportunistic associated with certain infection wich might endanger the life of immune compromised individuals, such endophthalmitis, wounds, bacteremia, septicemia, meningitis, pneumonia, endocarditis, pericarditis. It is a ubiquitous saprophyte of the environment, especially the soil, it can be met at all stages of the food production chain. The selection by the heat retaining endospores, is an important factor in the frequency of its isolation as a contaminant. The spore causes deterioration of food after its subsequent germination (Delmas et al., 2010). In Algeria, $B$. cereus is the 4th cause of foodborne outbreaks (INVS, 2004). Listeria monocytogenes, saprophytic ubiquitous (soil, plants, water) is an intracellular opportunistic pathogen agent.

\footnotetext{
* Corresponding Author

Djahoudi Abdelghani, Postal address: Faculty of Medicine, BP 205, Zaafrania Street, university Badji Mokhtar, Annaba 23000, Algeria.

E-mail: adjahoudi@yahoo.fr
}

Its ability to multiply at $4{ }^{\circ} \mathrm{C}$ allows it to reach high concentrations in foods stored in the refrigerator (Viuda et al., 2011). Listeria has gained increasing attention as a causative agent of listeriosis, with a mortality rate of $24 \%$ (Datta et al., 2003). It is also responsible for, bacteremia, meningitis, encephalitis, meningoencephalitis, miscarriage, premature births, stillbirths' human births etc. Infection occurs mainly due to the occasional contamination of food products, especially meat (Bubonja et al., 2011; Lauchlin et al., 2004). Many efforts have been made to guard against contamination by such microorganisms by the use of various types of preservatives.

However, capacity of resistance acquisition of these bacteria, forced into a continual search for new antimicrobials. In addition to tall the side effects that can generate these chemical conservative substances of synthetic origin. The plant world, presents an inexhaustible and renewable source whose traditional and medical use has been known since a long time. Among the aromatic plant species, the genus of Thymus offers a wide variety of natural substances with antimicrobial effects. The aim of this work is to evaluate the effectiveness of essential oil of Thymus ciliatus, an abundant endemic plant in the North -east of Algeria on both bacteria Bacillus cereus - Listeria monocytogenes. 
This species of Thyme produces an essential oil that has a very broad spectrum of action since it inhibits the growth of bacteria. This species produces an essential oil rich in phenolic compounds: Thymol and carvacrol, the most active antimicrobial molecules described to date(Kempf et al., 2011). The development of these herbs has affected several areas of the food industry (Ozkan et al., 2010). Where they can be applied as an effective alternative to chemical preservatives controlling pathogens in food products such as Bacillus cereus and Listeria monocytogenes. These strains are implicated in the contamination of food products stored at room temperature and the deterioration of refrigerated foods; also they are responsible for food poisoning.

\section{MATERIALS AND METHODS}

\section{Bacterial Strains}

We chose two strains which are implicated, one in the contamination of food products stored at room temperature and the other in the deterioration of refrigerated foods. Bacillus cereus originally isolated from a meat dish, preserved and identified by API system (Bio- Mérieux). Listeria monocytogenes is part of ATCC, kindly made available to us by the team at the Pasteur Institute in Algiers; were used as the test object.

\section{Essential oil}

\section{Plant material}

The aerial parts (stems, leaves and flowers) of Thymus ciliatus of Tawra in the province of Souk Ahras (Northeastern Algeria) were harvested in full bloom period (May-June 2012). The samples thus collected were dried in the open air and in the shade.

\section{Extraction of essential oil}

The essential oil was obtained by steam distillation using a LINKENS- NICKERSON type apparatus. The distillation was carried out by boiling $100 \mathrm{~g}$ of dry matter in 1 liter of water in a 2 liter flask surmounted by a column of $60 \mathrm{~cm}$ length connected to a condenser (Bruneton, 1999). After an extraction of 2 hours, the oil is recovered in small opaque bottle and stored at $4{ }^{\circ} \mathrm{C}$.

\section{Chemical analysis of the essential oil}

Chromatographic analysis of the extracted essential oil was performed on a gas chromatograph coupled to a type of mass spectrometer Shimadzu QP 2010. Column used is SE- 30 type 25 $\mathrm{m}$ in length, $0.25 \mathrm{~m}$ in diameter internally, the film thickness is 0.25 microns. The injection mode is split. Helium was used as carrier gas at a constant pressure of $25.6 \mathrm{KPa}$. The temperatures of the injector and transfer line were brought to $250{ }^{\circ} \mathrm{C}$. The oven temperature was programmed according to the following conditions:

Initial column temperature was $60{ }^{\circ} \mathrm{C}$, increasing the temperature of $3{ }^{\circ} \mathrm{C} / \mathrm{min}$ to $120{ }^{\circ} \mathrm{C}$, and is kept isothermal for 5 minutes then increased to $10{ }^{\circ} \mathrm{C} / \mathrm{min}$ to $180{ }^{\circ} \mathrm{C}$. The injected volume was $1 \mu$ l.
The analysis was performed in mode electron impact (EI)ionization with ionization energy of $70 \mathrm{EV}$ using in scan mode $(45-450 \mu)$. After obtaining the chromatogram of the essential oil, identification of chromatograms was done by querying the database NIST (National Institute of Standards and Technology). The internal normalization method was used for determining the amount of each component.

\section{Study of the Antibacterial Activity Aromatogram}

The antibacterial activity of the essential oil of Thymus ciliates on studied strains was determined by the solid medium diffusion method using sterile filter paper discs. The principle of this method is inspired of Antibiogramas recommended by the Clinical Laboratory Standards Institute (CLSI) and those of the Committee of French Society for Microbiology (CA-SFM ; EUCAST ; 2014).

This test is performed by depositing two sterile discs : one is impregnated with $20 \mu \mathrm{l}$ of the crude essential oil, the other is a witness disk devoid of any substance, on medium Muller-Hinton (MH) previously inoculated by a bacterial suspension concentration equivalent to $0.5 \mathrm{McF}$ arland $\left[10^{6}-10^{8} \mathrm{CFU} / \mathrm{ml}\right]$, (CFU= Colony- Forming Unit).

These prepared dishes were incubated at $37^{\circ} \mathrm{C}$ for $24 \mathrm{~h}$. The antibacterial activity, when present, is estimated by measuring the diameters of zones of inhibition around the discs.

\section{Determination of minimum inhibitory concentrations (MIC)}

MICs of the oil extracted on the studied bacterial strains were determined by the medium agar incorporation method as recommended by CLSI (CA-SFM ; EUCAST ; 2014).

A range of dilutions of the essential oil in DMSO (dimethylsulfoxide) were prepared so as to obtain Final concentrations of $1 \%, 0.5 \%, 0.4 \%, 0.3 \%, 0.25 \%, 0.2 \%, 0.15$ $\%, 0.1 \%, 0.075 \%, 0.05 \%, 0.025 \%$ and $0.012 \%$, essential oil per milliliter of culture medium (Djahoudi et al., 2011; Amrouni et al., 2014).

These dilutions are added to $\mathrm{MH}$ agar melted and cooled in a water bath at $45^{\circ} \mathrm{C}$. S pots of $2 \mu \mathrm{l}$ standardized inoculum to 0.5 McFarland are deposited on agar plates using a multiapplicator; witness boxes containing only $\mathrm{MH}$ were used as negative control.

All dishes are incubated in an incubator at $37^{\circ} \mathrm{C}$ for $24 \mathrm{~h}$. The MIC is defined as the lowest concentration in the presence of which no bacterial growth is visible to the naked eye similar to the growth of the strain on the control box (CA-SFM ; EUCAST ; 2014).

\section{RESULTS AND DISCUSSION}

\section{Yield of essential oil extracted}

The average yield of essential oil of Thymus ciliatus was $2.5 \%$. It is more important than that obtained from Thymus ciliatus of Morocco, which is $1.2 \%$ (Amarti et al., 2010). Thus, 
Thymus vulgaris essential oil of North America, obtained by steam distillation, gave a lower yield of about $1.8 \%$ (Yaouba et al., 2011). While essential oil Thymus piperella of Island of Great Comoro revealed an average yield of $1.31 \%$ (Satrani et al., 2010).

According to the study (Faleiro et al., 2003)on Portuguese Thyme:essential oil of Thymus mastichina, established a rather low yield of about $0.5 \%$.

Indeed, these variations in performance can be attributed, not only to the portion of the extracted plant, but also to climatic and environmental factors, the intensity of the metabolism of plants, species, age, the period of gathering and the specific geographical location of this species.

\section{Chemical composition of essential oil extracted}

Chemical analysis of the volatile essential oil components Thymus ciliatus GC-MS has allowed the identification of twenty four elements representing $99.87 \%$ of total oil (Table$1)$. It is composed mainly of phenolic monoterpenes represented by Thymol (67.78 \%) and carvacrol (2.70\%); followed by hydrogenated monoterpenes , p- cymene (12.25\%) associated to other components at relatively low levels, such as the pseudolimonene $(5.10 \%)$, the $\gamma$-terpinene $(4.42 \%)$.

Our results are similar to those of Cherchar et al., (2014)which showed that the essential oil of T. ciliatus species from Tlemcen (West Algeria) consists essentially of Thymol $(60.52 \%)$ followed by p-cymene $(17.2 \%)$ and $\gamma$-terpinene $(8.03 \%)$, while carvacrol is $(0.2 \%)$.

Indeed, the same results were obtained for the essential oil of $T$. vulgaris collected in the city of Ifran located in the Middle Atlas of Morocco which is Thymol chemotype (41.39\%), $\gamma$ terpinene (22.25\%) (El ouali et al ., 2013).

Thus, essential oil of $T$. serpyllum of western Himalayas (Kumaon region), has the same major compounds but with different percentages dominated by Thymol (60.1\%), followed by $\gamma$-terpinene $(13.8 \%)$ and of p-cymene $(10.4 \%)$ (El ouali et al., 2013).

By cons, another Tunisian variety of $T$. capitata (Zaghouan region) has a completely different composition from that of $T$. ciliatus with comparable percentages;carvacrol (88.98 $\%)$, p- cymene $(1.14 \%)$, Thymol $(0.51 \%)$ and $\gamma$ - terpinene $(0.40$ $\%)$ (El Abed et al., 2014).

Table 1: Chemical composition of essential oil of Thymus ciliatus.

\begin{tabular}{lll}
\hline Compound Name & $\boldsymbol{R T}$ & Content \\
& & $\mathbf{\%}$ \\
\hline$\alpha$-Thugène & 6.38 & $0.23 \%$ \\
1R- $\alpha$-pinène & 6.56 & $0.93 \%$ \\
1-octène-3-ol & 7.80 & $0.78 \%$ \\
$\alpha$-pinène & 8.12 & $0.45 \%$ \\
$\beta$ - thugène & 8.79 & $0.01 \%$ \\
$\alpha$ - terpinolène & 8.99 & $1.00 \%$ \\
p-cymène & $\mathbf{9 . 3 0}$ & $\mathbf{1 2 . 2 5 \%}$ \\
Limonène & 9.41 & $0.51 \%$ \\
$\gamma$-terpinène & 10.51 & $4.42 \%$ \\
3-carène & 10.87 & $0.28 \%$ \\
Pseudo-Limonène & 12.14 & $5.10 \%$ \\
5-isopropyl-2-methylbicyclo[3.1]hexan-2-ol & 15.33 & $0.23 \%$ \\
\hline
\end{tabular}

\begin{tabular}{lll}
\hline Thymol methyl ether & 17.74 & $0.93 \%$ \\
Thymoquinone & 18.45 & $0.60 \%$ \\
Thymol & $\mathbf{2 0 . 5 4}$ & $\mathbf{6 7 . 7 8 \%}$ \\
Carvacrol & 20.82 & $2.70 \%$ \\
$\alpha$-Cubebène & 23.73 & $0.007 \%$ \\
$\beta$-bourbonène & 24.11 & $0.02 \%$ \\
Caryophylène & 25.55 & $0.92 \%$ \\
5-Muurolène & 27.87 & $0.06 \%$ \\
$\Delta$-Cadinène & 29.74 & $0.13 \%$ \\
Epi-Bcyclosesquiphellandrène & 29.37 & $0.03 \%$ \\
2,5-Dimethoxyethylbenzène & 31.26 & $0.43 \%$ \\
\hline Total: & $\mathbf{9 9 . 8 7 \%}$ \\
\hline RT: & &
\end{tabular}

RT: retention time.

\section{Antibacterial activity of essential oil}

The diameters of the zones of inhibition around the discs loaded with essential oil are very important and so, class our strains, in the category of extremely sensitive microorganisms. Indeed inhibition diameters were $28.6 \mathrm{~mm}$ for L. monocytogenes and $40 \mathrm{~mm}$ for B. cereus and MICs of about $0.18 \mathrm{mg} / \mathrm{ml}$ (Table2).

Table 2: Diameter of inhibition and MIC EO of Thymus ciliates.

\begin{tabular}{|c|c|c|}
\hline \multirow{2}{*}{ Bacteria tested } & \multicolumn{2}{|c|}{ EO of $T$. ciliatus (S. Ahras) } \\
\hline & $\varnothing(\mathrm{mm})$ & MIC $(\mathrm{mg} / \mathrm{ml})$ \\
\hline L. monocytogenes ATCC 19118 & 28.6 & 0.18 \\
\hline B. cereus & 40 & 0.18 \\
\hline
\end{tabular}

Other studies have shown that the essential oil of Thymus capitata harvested in Tunisia (El Abed et al., 2014), has had a more importance activity on L. monocytogenes ATCC 19118and B. cereus with an inhibition diameter of 70 to $80 \mathrm{~mm}$ and MIC least low of 2.5 and $1.25 \mathrm{mg} / \mathrm{ml}$ for the two respective strains. For this, another essential oil of France Thymus vulgaris (Cristani et al., 2007) exerted an inhibitory effect on stem with low MIC $0,45 \mathrm{mg} / \mathrm{ml}$.

These values show excellent sensitivity of Gram-positive strains, tested, towards this essential oil. This would be attributed to the particular structure of their less complex membrane consisting of a thin layer of peptidoglycan in which proteins are related. Allowing hydrophobic molecules easily penetrate and act on the cell wall and into the cytoplasm (Burt et al., 2004; Cristani et al., 2007). The antibacterial action of essential oil (EO) of $T$. ciliatus is also related to its high content of phenolic derivatives (Thymol and carvacrol). These may destabilize the cytoplasmic membrane and interfere with energy metabolism and cellular integrity leading to cell death (Ultee et al., 2002; Nguefack et al., 2004; Cristani et al., 2007).

It should be noted that Thymol, main component of our $\mathrm{EO}$, is known for its broad spectrum of antibacterial activity (Dorman et al., 2000). Indeed, Thymol binds to membrane proteins and increased membrane permeability of the bacterial cell.

Other studies suggest that the volatile compound is responsible for the inactivation of enzymes, including those involved in the production of energy and synthesis of Structural components (Trombetta et al., 2005).

On the other hand, hydrogenated monoterpenes such as $\gamma$-terpinene and p-cymene are both precursors in the biosynthesis 
of carvacrol. Present in sufficient quantity (12.25\%), p- cymene facilitates intracellular penetration of carvacrol and potentiating its action (Ultee et al., 2002); it shows a high affinity for cell membranes and may disturb and affect them (Rassouli et al., 2006). Logically, its activity is the first link in the destabilization of cellular integrity process. This antibacterial effect is mainly provided by carvacrol. Thus, it has ATPase inhibitory activity (Gill and Holley, 2006) inducing dissipation proton- motive force by inhibiting other enzymes in the periplasmic space after the treatment of the bacterial cytoplasmic membrane (Ultee et al., 2002; Benarfa et al.,2006 ; Cristani et al.,2007 ; Xu et al., 2008).

While other minority compounds of our EO such as terpene hydrocarbons, pseudo-limonene known for its low antibacterial activity (Vardar Vnlu et al., 2003; Nejad Ebrahimi et al., 2008) and $\alpha$-terpinolene, can exert synergistic interactions. Their target and their mode of action remain to be determined.

\section{CONCLUSION}

Listeria monocytogenes and Bacillus cereus are two pathogenic bacteria responsible for food poisoning can be fatal. Many efforts have been made to protect food from contamination by this type of microorganisms by the use of various types of preservatives. However, the ability of these bacteria to develop resistance forced a continual search for new antimicrobials.

In this perspective, we were interested in the EO of Thymus ciliatus harvested in the region of Tawra (northeastern Algeria), and the GC / MS unveiled its chemotype "Thymol". This oil showed a very good antibacterial activity against pathogenic strains of Listeria monocytogenes and Bacillus cereus.

This result suggests the use of such molecules in food as a substitute for conventional chemical preservatives. Knowing that in terms of taste, Thyme is much appreciated and constitutes an ingredient in several recipes, this opens the prospect of its use for the prevention and fight against deterioration of food stored at room temperature or $4{ }^{\circ} \mathrm{C}$.

In addition to its economic impact, this EO would contribute to the fight against food poisoning.

\section{REFERENCES}

Amarti F, Satrani B, Ghanmi M, Farah A, Aafi A, Aarab L, El Ajjouri M. Composition chimique et activité antimicrobienne des huiles essentielles de Thymus algeriensis Boiss. \& Reut. Et Thymus ciliates (Desf.) Benth. Du Maroc. Biotechnol. Agron. Soc. Environ, 2010 ;14 : 141-148.

Amrouni S, TouatiM, Hadef Y, Djahoudi A. Effet de l'huile essentielle d'Origanumvulgare et de Thymus ciliatus sur Pseudomonas aeruginosa VIM-2 carbapénèmase.Phytothérapie,2014 ;125-127.

Benarfa A, Combes S, Preziosi-Belloy L, Gontard N, Chalier P.Antibacterial activity of carvacrol related to its chemical structure. LettApplMicrobiol,2006 ; $43: 149-154$.

Bruneton J. 1999. Pharmacognosie, Phytochimie, plantes médicinales. Tec. Et Doc. Lavoisier. 3emeédition. 484-488

Bubonja-Sonje M, Giacometti J, Abram A. Antioxidant and antilisterial activity of olive oil, cocoa and rosemary extract polyphenols. Food Chemistry, 2011; 127(4): 1821-1827.

Burt S. Essential oils: their antibacterial properties and potential applications in foods. International Journal of Food Microbiology, 2004; 94: 223-253.
Cherchar H, Kabouche A, Kabouche Z. Comparative compositions of essential oils of Thymus growingin various soils and climates of North Africa. J Mater EnvironSci, 2014; 5 (1): 298-303.

Comité de l'Antibiogramme de la Société Française de Microbiologie [CA-SFM ; EUCAST] ; 2014- Volume 2.

Cristani M, d'Arrigo M, Mandalari G, Castelli F, SarpietroMG, Micieli D, Venuti V, BisignanoG.Interaction of four monoterpenes contained in essential oils with model membranes: implications for their antibacterial activities. J Agric Food Chem, 2007 ;55: 6300-6308.

Datta AR, MiliotisMD, Bier JW. 2003. Listeria monocytogenes, in International Handbook of Foodborne Pathogens. New York, NY, USA. Marcel Dekker. pp. 105- 121

Delmas G, Jourdan da Silva N, Pihier N, Weill FX, Vaillant V, de Valk H. Les toxi-infections alimentaires collectives en France entre 2006 et 2008. Bulletin Epidémiologique Hebdomadaire, 2010; 31-32; 344 348.

Djahoudi A, Toubal O, BouzabataA. Preliminary Studies and Antimicrobial evaluation of the Aerial Parts ofGenistanumidica ssp. Numidica.Journal of Life Sciences, 2011;5: 954-959.

Dorman HJD, DeansSG,Antimicrobial agents from plants: antibacterial activity of plant volatile oils. J Appl Microbiol, 2000; 88: 308-316

El Abed N, Kaabi B, Smaali MI, Chabbouh M, Habibi K, MejriM,Marzouki MN, Ben Hadj Ahmed S. Chemical composition, antioxidant and antimicrobial activities of Thymus capitataessential oil with its preservative effect against Listeria monocytogenesInoculated in minced beef meat. Evidence-Based Complementary and Alternative Medicine, 2014; 11.

EL oualiLalami A, EL-akhal F, Ouedrhiri W, Ouazzani CH, Guemmouh R, Greche H. Synergistic antibacterial activity between Thymus vulgaris and Pimpinellaanisum essential oils and methanol extracts.Journal of Ethnopharmacology,2013;116 (3): 403-406.

Faleiro MF, Miguel MG, Venancio F, Taveares R, Brito GT , Figueiredo AC, Pedro LG.Antibacterial activity of the essential oils from Portugues endemic spices of thymus. Letter in applied Microbiology, $2003 ; 36-40$.

Gill AO, Holley RA. Inhibition of membrane bound ATPases of Escherichia coli and Listeria monocytogenes by plant oil aromatics. Int J Food Microbial, 2006; 111: 361-379.

INVS. 2004. Morbiditéetmortalité dues aux maladies infectieusesd'originealimentaire en France, Rapport de l'Institut de Veille Sanitaire.http://www.invs.sante.fr/publications/2004/inf_origine_alimentai re, Consulté en juin 2011.

Kempf M, Eveillard M, Kowalczyk F, RossinesE, Panhelleux G, Joly-Guillou ML.Antibacterial activity against 224 clinical bacterial strains of JCA 250 and JCA 251 compounds containing essential oils provided from Aroma Technologies research. Pathologie Biologie, 2011; 59: 39-43.

McLauchlin J, Mitchell RT, Smerdon WJ, Jewell K. Listeria monocytogenes and listeriosis: a review of hazard characterisation for use in microbiological risk assessment of foods. International Journal Food Microbiology. 2004; 92(1), 15-33.

Nejad Ebrahimi S, Hadian J, Mirjalil MH, Sonboli A, Yousefzadi M. Essential oil composition and antibacterial activity of thymus caramanicus at different phonological stages. Food chemistry, 2008; 110(4): 927-931.

Nguefack J, Budde BB, Jakobsen M. Five essential oils from aromatic plants of Cameroon: their antibacterial activity and ability to permeabilize the cytoplasmic membrane of Listeria innocuaexamined by flow cytometry. Lett Appl Microbiol, 2004; 39: 395-400.

Rassouli I, Rezaei MB, Allameh A. Ultrastructural studies on antimicrobial efficacy of thyme essential oils on Listeria monocytogenes. Int J Infect Dis, 2006; 10: 236-241.

Ozkan G, Sagdic O, GokturkR S, Unal O, AlbayrakS. Study on chemical composition and biological activities of essential oil and extract from Salvia pisidica.LWT-FoodScience and Technology, 2010 ; 43(1) : 186-190.

Satrani B, Farah A, Talbi M. Composition chimique et activité antimicrobienne des huiles essentielles de Saturejacalamintha et 
Saturejaalpina du Maroc. Ann. Falsif. Expert. Chim. Toxicol, 2006 ; 94(956) : 241-250.

Tossa P, Villeroy F, Schaefer JL, Manel J. 2009. Intoxication alimentaire parBacilluscereus: à propos d'un cas d'hépatite fulminante suite à l'ingestion d'un plat de pâtes, 47ème congrès de Société de Toxicologie Clinique, STC, Toulouse, France.

Trombetta D, Castelli F, Sarpietro M, Venuti V, Cristani M, Daniel C. Mecanisme of antibacterial action of three monoterpenes. AntimicrobAgents Chemother, 2005;49: 2474-2478.

Ultee A, Bennik MHJ, Moezelaar R. The phenolic hydroxyl group of Carvacrol is essential for action against the food-borne pathogen Bacillus cereus. Appl Environ Microbiol,2002;68: 1561-1568.

Vardar Vnlu G, Candan F, Sokmen A. Antimicrobial and antioxidant activity of the essential oil and methanol extracts of thymus pectinatus Fisch ET Mey. Var. pectinatus (Lamiaceae).Journal of Agricultural and food chemistry, 2003;51(1): 63-67.

Viuda-Martos M, Mohamadyb MA, Fernandez-Lopeza J. In vitro antioxidant and antibacterial activities of essentials oils obtained from Egyptian aromatic plants. Food Control, 2011; 22: 1715-1722.
Yaouba A, Tatsadjieu N, Léopold and Mbofung C. Mycelia growth inhibition of some Aspergillus and Fusarium species by essential oils and their potential use as antiradical agent. Agric Biol J N Am, 2011; 2(11):1362-1367.

Xu J, Zhou F, Ji BP, Pei RS, XuN. The antibacterial mechanism ofcarvacrol and Thymol against Escherichia coli. Lett Appl Microbiol, 2008;47: 174-179.

\section{How to cite this article:}

Heni S, Bennadja S, Djahoudia. Chemical composition and antibacterial activity of the essential oil of Thymus ciliatus growing wild in North Eastern Algeria. J App Pharm Sci, 2015; 5 (12): 056060 . 